\title{
NEK2 wt Allele
}

National Cancer Institute

\section{Source}

National Cancer Institute. NEK2 wt Allele. NCI Thesaurus. Code C138105.

Human NEK2 wild-type allele is located in the vicinity of $1 \mathrm{q} 32.3$ and is approximately 17 $\mathrm{kb}$ in length. This allele, which encodes serine/threonine-protein kinase Nek2 protein, is involved in both the cell cycle and protein phosphorylation. Mutation of the gene may be associated with retinitis pigmentosa. 